leegyszerũsítés és a nagyközönséget félrevezetheti ,hanyatlás"-nak nevezni a fejlett nagyvárosok lakói egy részének kertes elốvárosokba történổ kiköltözését, s ,lendületes urbanizáción"-nak a fejlő́dô országok falusi nyomorultjainak szívszorító bemenekủlését a nagyvázosok nyomortelepeire (amirôl az elöszó más tészén is szó esik).

A biráló persze mindig az, „ördög ügyvédje", kifogásait listázza hosszasan. Kifogásai- mat igen sikeres, hézagpótló munkával kapcsolatban adtam elố. Jó stílusban, a lexikonok száraz nyelvezetét elkerülve, tudományosan megalapozott fỏldrajzi ismereteket kapunk. Különösen PROBÄLD FERENC címszavait jó olvasni. E munkának könyvespolcunkon a köny. nyen elérhető könyvek között a helye.

Enyedi György

\title{
P. J. CLCKE: AN INTRODUCTION TO RURAL SETTLEMENT PLANNING
}

(Bevezetés a falusi településtervezésbe. Methuen, London, New York, 1983. 380 p.)

Egy szerencsés véletlen folytán, rövid időn belül mår a harmadik CLOKE kötet recenzálására van módom. Igy talán nem túlzás, ha azt álítom, hogy lassan személyes ismeretség hijån is ismerem a szerzőt, s egy kivételesen gazdag, termékeny életmũ bontakozik ki elốttem. Imponáló, hogy az egymást követő munkák (Key settlements in rural areas, Rural resource management) gondolatsora egyre bốviul, spirálisan teljesedik ki. A lampeteri St. Davis Egyetem alkotó ereje teljében lévő geog. ráfusának könyvei mindig pontosan arról szólnak, amit a szerzójük igér, igy ez körültekintố alapossággal vezeti be az olvasót $\mathbf{a z}$ angolszász nyelvterület falusi településtervezésének elvi, módszertani s gyakorlati problémáiba.

A könyv aktualitását az adja, hogy NagyBritanniában a falusi térségek népessége 1961 71 között 7,5 \%-kal, 1971-81 között 10,2 \%kal emelkedett. A bevezetô adatokat és kartogramokat tartalmazó fejezet végén egyérelmüen kiemeli a szerző: , A rurális térségek helyzetének megváltozása, újranépesedése rendkívil komplex és sokkomponensü jelenség, ezért mindent meg kell tennünk, hogy megértsủk ezeket az új trendeket, a tervezésnek pedig a falusi hagyományok ápolására törekedve kell aktivan beavatkoznia a folyamatokba." A 280 oldalas könyv 12, közel azonos terjedelmú fejezetböl áll, amelyek további 4-5 kisebb részre bomlanak, igy a mũ igen jól tagolt, áttekinthetổ és követhetổ.

A város és a falu fogalmának meghatározása után a szerzố az angol falusi átalakulás legfon- tosabb tényezóit elemzi a múltban és a jelenben. A XIX. század kapitalista iparfejlôdése révén kialakult városok és urbanizációjuk kiteljesedésének rövid bemutatása után megállapítja, hogy az utóbbi 30 év hozott ismét más irányú változást és újabb konfliktusokat. Ezek szerint: a vidéki (falusi) területek elsódlegesen fontossá váltak a városi népesség rekreációjában, ső́t, a falvak a városi polgárok elvándorlásának céltelepülései lettek, ugyanakkor az agrártevékenységnek a nagyfokú modernizációja miatt annak faluval való kapesolata lazábbá vált, illetve jelentős területi differenciák keletkeztek a falusi térségek között például a népesség elöregedését illetően.

Bemutat néhány olyan vizsgálati eredményt is, amelyek e területi egyenlớtlenségeket elemzik (pl. az északi-tengeri olajmezốk hatását), majd többféle falutipológiát ismertet, végül MOSS folyamatát írja le. E szerint a faluátalakulás folyamata a következó: ipari forradalom - városi növekedés - városba áramló falusi népesség - csökkenố falusi kapacitások - közlekedés fejlesztés - ingázás - a motorizáció és kommunikáció fejlődése - a turizmus és a rekreáció - az utóbbi szempontjából jól elérhetô falvak - második otthonok - az új falusi funkciók térségeinek központi támogatása folytatódó leépülés az új falusi funkciókkal nem rendelkező rurális tẻrségekben - szelektív falusi expanzió (kulcstelepülések) - a jó termóföldek elvesztése - migráció a falusi kulcstelepülések felé.

A lényegében teljesen faluföldrajzinak minô- 
síthető első három fejezet után hét a konkrét falutervezéssel, annak tudományos megalapozásával, metodikájával foglalkozik, és példák sokaságával illusztráija a kiválasztott falusi térségek fejlesztésének speciális eseteit. Kifejti, hogy négy tényezó figyelembevételével kell megalapozni a falufejlesztést, ezek: a politikai, a múszaki-tervezési, a társadalmi és a gazdasági elméleti alapok. Ezután sorra veszi a különböző tervek fổbb formáit: (I) a települések hálózati hierarchiájára építö, (II) a gazdaságossági (normativ) küszöbökkel számoló és (III) a központok (kulcstelepülések) növekedésére alapozó terveket. Itt található a (113 118. oldalakon) a recenzor számára a könyv talán legérdekesebb része, amikor a ,direkt utasításos" szovjet, illetve a decentralizált „,spontán" angol falupolitikát hasonlítja össze CLOKE.

A 4-9-ig terjedó fejezetekben a falusi településfejlesztés példatárából „,szemezget” a szerző. Miután egyik kollegájával Anglia és Wales valamennyi ilyen tervét összegyújtötték és kiértékelték, hallatlanul színesek és érdekesek ezek a részek, amelyek a hatféle angol falupolitikát értékelik. Nem kevésbé érdekes a világ-kitekintés sem, ahol a 165. oldalon hazánkról is szól egy bekezdés: a magyar falufejlesztés a pénzeszközök egyenlốtlen ,területi és népességi" redisztribucióján alapszik, $\mathrm{s}$ a szerzö szerint olyan ,kevert gazdaság vagyunk", amelyben szocialista egyenlöség ideáját csaknem teljesen ,kompromittálja" a gazdasági realitás. Hangsúlyozza, hogy a magyar falvak infrastrukturális fejlesztése sokkal kevesebb szubvenciót kapott, mint a városoké (pl. az elektromos áram és a közlekedés is drágább). Szól e néhány sorban arról is, hogy a központi akarat igen erősen érvényesül a területi tervezésben, de mégis fel-felbukkan a helyi érdekek érvényesítésének igénye, koordinációja. Hozzánk hasonlitva, pozitiv ellenpéldaként a skandináv államok helyi igényekre épülö falupolitikáját mutatja be.

A könyvet záró „,Mi lesz a jövő" címü fejezetben visszautalva a korábbiakra, CLOKE több lehetôséget vázol fel: elsôdleges szükségletként említi azt, hogy a „falu hangjának" szervezeti nyilvánosságot kell kapnia, ezután figyelemmel kell lenni: az életmód és környezet igényeire, hatásaira, a közigazgatásra, a falusi ellátásban pedig: a kereskedelemre, a közlekedésre, az oktatásra, az egészségügyre, a szociális gondozásra. A 347. oldalon azt írja: „,A tervezók sem tudhatnak mindent jól, s ezért ne erőltessenek semmilyen változást" - jegyzi meg, a kutatók pedig igyekezzenek valamennyi folyamatot részletesen elemezni, hogy eredményeik adaptálhatók legyenek.

Azt hiszem, a tartalmi ismertetésból egyértelmúen kiviláglik, milyen gazdag, széles ismeretanyagokon alapuló munka CLOKE könyve, s csak sajnálni lehet, hogy - bár egyes részeiben a magyar településtudomány is megtette már ezeket a lépéseket - mi mégsem tudunk hasonlót felmutatni. MENDOL TIBOR negyedszázada megjelent könyve óta nincs hasonló a honi piacon. Ezért hát le kellene fordítani, vagy írni egy hasonlót, hiszen a falusi átalakulás Magyarországon tapasztalható új folyamatai ezt előbb-utóbb kényszerúen igényelnék, mint a szerző írja: geográfusok, közgazdászok, szociológusok és tervezők ,együttgondolkodásával".

$S$ végül még egy személyes megiegyzés. A könyv hangvétele végig tárgyszerú, de izgalmas, s mindvégig ott érzik mögötte az író, alkotó ember szubjektuma. Azt írja CLOKE az előszóban: 1981 jó év volt a családjában, megszületett a kislánya, megírta ezt a könyvet, sốt, kedvenc focicsapata, a Tottenham, megnyerte az Angol kupát. Nálunk lassan a ,tudományos tárgyszerúség" megöli az írót, $s$ alig vétetik figyelembe az alkotó személyisége, élete teljessége. Ósszefoglalva: CLOKE könyvét az, ,együttgondolkodás" igényével ajánlom mind a négy imént felsorolt szakma hivatásos múvelőjének, abban a reményben, hogy talán mi is tudunk a közeljövő́ben hasonlót produkálni.

Csatári Bálint 